\title{
Effect of Initial Microstructure on Creep Strength of ASME Grade T91 Steel
}

\author{
Kota SAWADA,${ }^{1) *}$ Kaoru SEKIDO, ${ }^{1)}$ Kazuhiro KIMURA, ${ }^{1)}$ Ko ARISUE, ${ }^{2)}$ Masaki HONDA ${ }^{2)}$ Nobuyoshi KOMAI ${ }^{2)}$ \\ Norihide FUKUZAWA, ${ }^{3)}$ Tomonori UENO, ${ }^{3)}$ Nobuaki SHIMOHATA ${ }^{4)}$ Hitoshi NAKATOMI, ${ }^{4)}$ Kenji TAKAGI ${ }^{4)}$ \\ Takahiro KIMURA, ${ }^{5)}$ Kyohei NOMURA $^{5)}$ and Keiji KUBUSHIRO ${ }^{5)}$ \\ 1) National Institute for Materials Science, 1-2-1 Sengen, Tsukuba, Ibaraki, 305-0047 Japan. \\ 2) Mitsubishi Heavy Industries, Ltd., 5-717-1, Fukahori-Machi, Nagasaki, 851-0392 Japan. \\ 3) Hitachi Metals Ltd., 1240-2, Hashima-cho, Yasugi, Shimane, 692-8601 Japan. \\ 4) Electric Power Development Co., Ltd., 15-1, Ginza 6-Chome, Chuo-ku, Tokyo, 104-8165 Japan. \\ 5) IHI Corporation, 1, Shin-nakahara-cho, Isogo-ku, Yokohama, 235-8501 Japan.
}

(Received on June 10, 2019; accepted on August 22, 2019; originally published in Tetsu-to-Hagané, Vol. 105, 2019, No. 5, pp. 433-442; J-STAGE Advance published date: October 11, 2019)

\begin{abstract}
To clarify the cause of heat-to-heat variation in the creep strength of Grade T91 steels, the influence of the initial microstructure on creep strength was investigated. The distribution of chromium concentration considered to be remaining segregation was observed as corresponding to lamellar contrasts parallel to the longitudinal direction of the boiler tube. Standard deviation (SD) of $\Delta \mathrm{Cr}$ was employed as an indicator of the degree of segregation, and a good correlation was found between the SD of $\Delta \mathrm{Cr}$ and the creep rupture life at $650^{\circ} \mathrm{C}$. Remaining segregation was reduced by renormalizing heat treatment at $1200^{\circ} \mathrm{C}$ instead of $1250^{\circ} \mathrm{C}$. The creep rupture life of steel subjected to renormalizing heat treatment at $1200^{\circ} \mathrm{C}$ and tempering at $760^{\circ} \mathrm{C}$, followed by normalizing and tempering under standard heat treatment conditions for Grade T91 steel, was prolonged by a factor of 2.3-2.8. The strengthening effect of renormalizing at $1200^{\circ} \mathrm{C}$ to reduce the remaining segregation was confirmed by creep tests up to about $10000 \mathrm{~h}$ at $600^{\circ} \mathrm{C}$ and $650^{\circ} \mathrm{C}$. Decreases in the number density of $\mathrm{M}_{23} \mathrm{C}_{6}$ carbide particles, length of high-angle boundaries and average KAM values during creep exposure are promoted by the presence of remaining segregation. Since diffusion is enhanced by the concentration gradient of elements, degradation due to microstructural change is promoted by the presence of remaining segregation. Segregation should be reduced to obtain high creep strength with homogenized concentration of chemical composition.
\end{abstract}

KEY WORDS: creep strength enhanced ferritic steel; T91; creep strength; segregation.

\section{Introduction}

Many types of creep strength enhanced ferritic (CSEF) steels have been developed for boiler tubes, main steam pipes and headers in thermal power plants after modified 9Cr-1Mo steel was standardized as Grade 91 in the early 1980s. ${ }^{1)}$ CSEF steels improve the steam temperature and thermal efficiency of thermal power plants due to their higher strength at elevated temperatures compared to that of conventional steels. However, it has been pointed out that the creep strength of CSEF steel degraded in the longterm. $^{2-4)}$ Creep strength of CSEF steels was found to be lower in welded joints than in the base metal. ${ }^{5)}$ Therefore, the material specifications and allowable stress have been reviewed based on the re-evaluation of the creep strength of CSEF steels. ${ }^{6-8)}$ Moreover, the weld strength reduction factors and creep life evaluation equation have also been determined for CSEF steels. ${ }^{9-12)}$

In Japan, the allowable stress for modified 9Cr-1Mo steel

\footnotetext{
* Corresponding author: E-mail: SAWADA.Kota@nims.go.jp DOI: https://doi.org/10.2355/isijinternational.ISIJINT-2019-358
}

was revised in 2007 and 2014 based on the re-evaluation of creep strength. ${ }^{7,8)}$ However, the Assessment Committee on Creep Data of High Chromium Steels proposed a further revision in 2015 because the new creep strength data obtained after the 2014 review showed relatively low creep strength. ${ }^{13)}$ It has been reported for boiler tubes used in the NIMS Creep Data Sheet Project that the creep strength of the tubes sampled in 2000 and 2001 was lower than that of the tubes sampled in $1990 .{ }^{14)}$ Therefore, to clarify the reason for the heat-to-heat variation in the creep strength of ASME SA-213/SA-213M Grade T91 steels, the effect of the initial microstructure on creep strength was investigated.

\section{Experimental Procedures}

The materials examined were modified 9Cr-1Mo steel tubes for boilers (ASME SA-213/SA-213M Grade T91). Six heats obtained from the NIMS Creep Data Sheet were selected for investigation. Chemical compositions, heat treatment conditions, product dimensions and austenite grain size number are listed in Table 1 together with the requirements for chemical composition and heat treatment condi- 
ISIJ International, Vol. 60 (2020), No. 2

Table 1. Chemical composition (mass\%), heat treatment condition, size of tube and grain size number of the steels studied

\begin{tabular}{|c|c|c|c|c|c|c|c|c|c|c|c|c|c|c|c|}
\hline & & $\mathrm{C}$ & $\mathrm{Si}$ & $\mathrm{Mn}$ & $\mathrm{P}$ & $\mathrm{S}$ & $\mathrm{Ni}$ & $\mathrm{Cr}$ & Mo & V & $\mathrm{Nb}$ & $\mathrm{N}$ & $\mathrm{A} 1$ & $\mathrm{Ti}$ & $\mathrm{Zr}$ \\
\hline \multirow{2}{*}{ Spec. } & METI & \multirow{2}{*}{$\begin{array}{c}0.07 \\
-0.14\end{array}$} & \multirow{2}{*}{$\begin{array}{c}0.20 \\
-0.50\end{array}$} & \multirow{2}{*}{$\begin{array}{c}0.30 \\
-0.60\end{array}$} & \multirow{2}{*}{$\leqq 0.020$} & \multirow{2}{*}{$\leqq 0.010$} & \multirow{2}{*}{$\leqq 0.40$} & \multirow{2}{*}{$\begin{array}{c}8.0 \\
-9.5\end{array}$} & \multirow{2}{*}{$\begin{array}{c}0.85 \\
-1.05\end{array}$} & \multirow{2}{*}{$\begin{array}{c}0.18 \\
-0.25\end{array}$} & \multirow{2}{*}{$\begin{array}{c}0.06 \\
-0.10\end{array}$} & \multirow{2}{*}{$\begin{array}{c}0.030 \\
-0.070\end{array}$} & $\leqq 0.04$ & - & - \\
\hline & ASME & & & & & & & & & & & & $\leqq 0.02$ & $\leqq 0.01$ & $\leqq 0.01$ \\
\hline \multicolumn{2}{|c|}{ MGA } & 0.10 & 0.38 & 0.40 & 0.015 & 0.001 & 0.12 & 8.53 & 0.96 & 0.21 & 0.076 & 0.050 & 0.014 & $<0.001$ & $<0.001$ \\
\hline \multicolumn{2}{|c|}{ MGB } & 0.09 & 0.34 & 0.45 & 0.015 & 0.001 & 0.20 & 8.51 & 0.90 & 0.205 & 0.076 & 0.042 & 0.016 & 0.001 & $<0.001$ \\
\hline \multicolumn{2}{|c|}{ MGC } & 0.09 & 0.29 & 0.35 & 0.009 & 0.002 & 0.28 & 8.70 & 0.90 & 0.22 & 0.072 & 0.044 & 0.001 & $<0.001$ & $<0.001$ \\
\hline \multicolumn{2}{|c|}{ MGD } & 0.10 & 0.29 & 0.41 & 0.010 & 0.001 & 0.10 & 8.41 & 0.90 & 0.185 & 0.07 & 0.048 & 0.016 & 0.001 & $<0.001$ \\
\hline \multicolumn{2}{|c|}{ MGF } & 0.11 & 0.25 & 0.42 & 0.013 & 0.001 & 0.06 & 8.41 & 0.91 & 0.20 & 0.08 & 0.053 & 0.001 & 0.006 & $<0.001$ \\
\hline \multicolumn{2}{|c|}{ MGG } & 0.10 & 0.38 & 0.37 & 0.018 & 0.002 & 0.12 & 8.60 & 0.95 & 0.190 & 0.08 & 0.0458 & 0.002 & $<0.001$ & $<0.001$ \\
\hline
\end{tabular}

\begin{tabular}{|c|c|c|c|c|}
\hline & Normalizing & Tempering & Dimension & G.S. \\
\hline METI & $\geqq 1040^{\circ} \mathrm{C}$ & $\geqq 730^{\circ} \mathrm{C}$ & - & - \\
\hline ASME & $1040-1080^{\circ} \mathrm{C}$ & $730-800^{\circ} \mathrm{C}$ & - & - \\
\hline MGA & $1045^{\circ} \mathrm{C} / 10 \mathrm{~min} . \mathrm{AC}$ & $780^{\circ} \mathrm{C} / 60 \mathrm{~min} . \mathrm{AC}$ & $50.8 \mathrm{OD}, 8.0 \mathrm{t}$ & 10.1 \\
\hline MGB & $1050^{\circ} \mathrm{C} / 60 \mathrm{~min} . \mathrm{AC}$ & $760^{\circ} \mathrm{C} / 60 \mathrm{~min} . \mathrm{AC}$ & $50.8 \mathrm{OD}, 7.3 \mathrm{t}$ & 9.3 \\
\hline MGC & $1050^{\circ} \mathrm{C} / 10 \mathrm{~min} . \mathrm{AC}$ & $765^{\circ} \mathrm{C} / 30 \mathrm{~min} . \mathrm{AC}$ & $50.8 \mathrm{OD}, 8.0 \mathrm{t}$ & 10.2 \\
\hline MGD & $1050^{\circ} \mathrm{C} / 10 \mathrm{~min} . \mathrm{AC}$ & $780^{\circ} \mathrm{C} / 40 \mathrm{~min} . \mathrm{AC}$ & $50.8 \mathrm{OD}, 8.9 \mathrm{t}$ & 10.2 \\
\hline MGF & $1045^{\circ} \mathrm{C} / 60 \mathrm{~min} . \mathrm{AC}$ & $780^{\circ} \mathrm{C} / 60 \mathrm{~min} . \mathrm{AC}$ & $50.8 \mathrm{OD}, 8.7 \mathrm{t}$ & 10.6 \\
\hline MGG & $1050^{\circ} \mathrm{C} / 15 \mathrm{~min} . \mathrm{AC}$ & $790^{\circ} \mathrm{C} / 60 \mathrm{~min} . \mathrm{AC}$ & $50.8 \mathrm{OD}, 9.0 \mathrm{t}$ & 10.7 \\
\hline
\end{tabular}

METI: The Interpretation for the Technical Standard for Thermal Power Plant, KA-STBA28

ASME: Boiler and Pressure Vessel Code, SA-213/SA-213M Grade T91

AC: air cooling

OD: outer diameter

$\mathrm{t}$ : thickness

tions in the ASME specifications ${ }^{15)}$ and KA-STBA28. ${ }^{16)}$ The chemical compositions and heat treatment conditions of all investigated steels are within the range of these specifications. Creep tests were performed under constant load in air, using specimens $30 \mathrm{~mm}$ in gauge length and $6 \mathrm{~mm}$ in gauge diameter. Microstructures of as-received samples, gauge and grip portions of creep ruptured samples, were observed by optical microscopy, SEM and TEM, and analyzed using EPMA, SEM-EDS and SEM-EBSD. Vilella's Solution was used for etching for optical microscopy.

\section{Results and Discussion}

\subsection{Creep Strength Properties}

Stress versus time-to-rupture curves for the six heats at $600{ }^{\circ} \mathrm{C}, 625^{\circ} \mathrm{C}$ and $650^{\circ} \mathrm{C}$ are shown in Fig. 1. The creep strengths of MGD, MGF and MGG were lower than those of MGA, MGB and MGC. The difference in creep strength increased with increasing testing temperature. It was reported that $\mathrm{Ni}$ and $\mathrm{Al}$ decrease the creep strength. ${ }^{5,17)}$ However, at $650^{\circ} \mathrm{C}$, no correlation was observed between the heat-to-heat variation of the creep strength for the six heats and the amount of $\mathrm{Ni}$ and $\mathrm{Al}$. No effect of the $\mathrm{Al}$ content on creep strength has been reported ${ }^{18)}$ when the $\mathrm{Al}$ content was less than 0.025 mass \%. In short, no correlation was observed between the creep strength and $\mathrm{Al}$ content because the $\mathrm{Al}$ content of the six heats was less than 0.025 mass $\%$.

\subsection{Microstructural Observation}

For the as-received MGA heat sample, an optical micro-

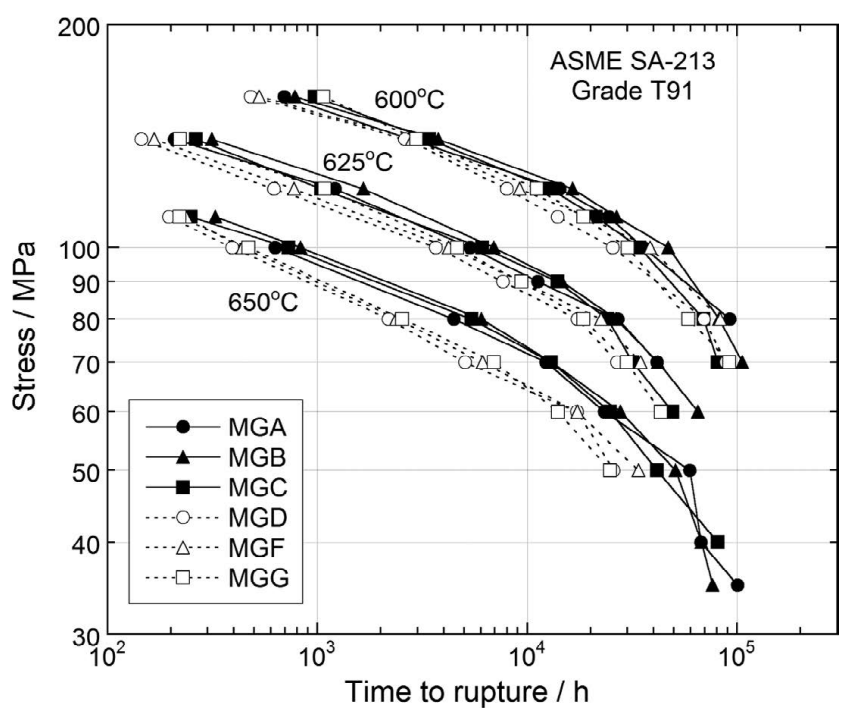

Fig. 1. Creep rupture strengths of MGA, MGB, MGC, MGD, MGF and MGG heats of Grade T91 steel at 600, 625 and $650^{\circ} \mathrm{C}$.

graph of a cross section parallel to the longitudinal direction is shown in Fig. 2. A large number of layered contrasts were observed parallel to the longitudinal direction of the boiler tube. Layered contrasts were also confirmed for other heats.

For the as-received MGD heat sample, elemental maps of $\mathrm{Cr}, \mathrm{C}, \mathrm{V}$ and $\mathrm{Nb}$ obtained by EPMA are shown in Fig. 3. Layers with a high concentration of alloying elements were observed parallel to the longitudinal direction of the boiler tube. The concentration of $\mathrm{Cr}, \mathrm{C}, \mathrm{V}$ and $\mathrm{Nb}$ was high 


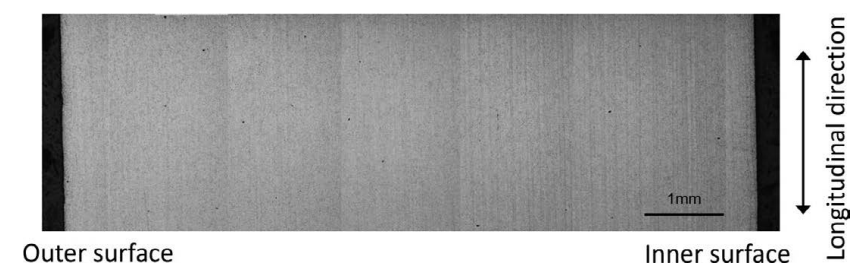

Fig. 2. Macrostructure of MGA heat of Grade T91 steel in the as received condition.
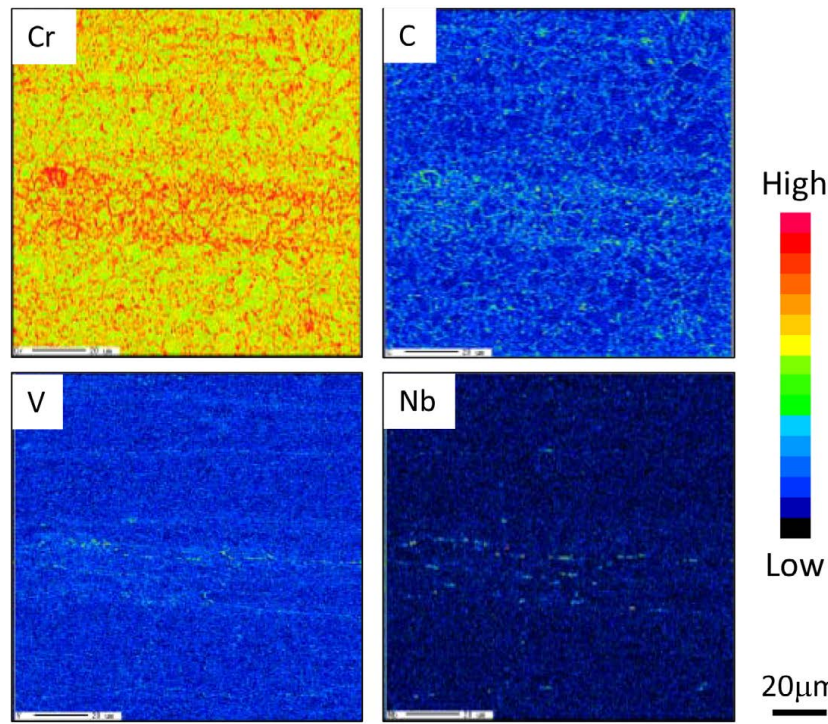

Longitudinal direction

Fig. 3. Elemental maps of EPMA on chromium, carbon, vanadium and niobium of MGD heat of Grade T91 steel in the as received condition. (Online version in color.)

in the same area.

Also for the as-received MGD heat sample, elemental maps of $\mathrm{Cr}, \mathrm{Nb}, \mathrm{V}$ and $\mathrm{Al}$ on carbon-extracted replica were obtained by STEM-EDS, as shown in Fig. 4. $\mathrm{M}_{23} \mathrm{C}_{6}$ carbides shown in red and V-rich MX particles shown in blue were distributed throughout the area. A large number of $\mathrm{Nb}$-rich $\mathrm{MX}$ particles shown in green and inclusions $\left(\mathrm{Al}_{2} \mathrm{O}_{3}\right)$ shown in white were aligned along the longitudinal direction, together with $\mathrm{M}_{23} \mathrm{C}_{6}$ carbides and $\mathrm{V}$-rich $\mathrm{MX}$ particles.

Consequently, the layered contrasts shown in Fig. 2 correspond to layers with a high concentration of alloying elements and a large number of precipitates and inclusions. It is presumed that the areas where alloying elements concentrated due to solidifying segregation were thinly rolled by hot extrusion, causing the formation of a layered microstructure with a different concentration of alloying elements.

In order to compare the area containing solidifying segregation (segregation zone) and other areas, the IPF map for the as-received MGA heat sample was observed by SEM-EBSD, as shown in Fig. 5. The black triangle at the top center of the figure is an indentation indicating the location of the segregation zone. The sizes of prior austenite grains, packets and blocks were smaller in the segregation zone (B) than in the other area (A). In the segregation zone, the growth of prior austenite grains may be retarded by the presence of undissolved $\mathrm{Nb}$-rich $\mathrm{MX}$ particles that remained even after normalizing at $1050^{\circ} \mathrm{C}$.

Hardness (HV 0.05) distribution along the thickness

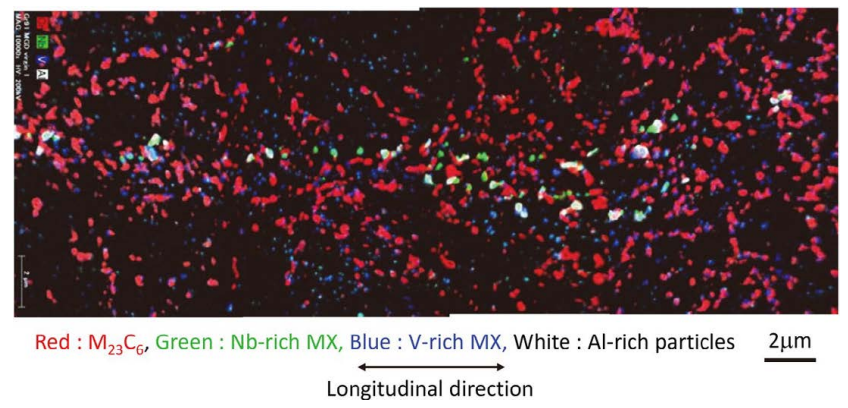

Fig. 4. STEM-EDS image of carbon extracted replica taken from MGD heat of Grade T91 steel in the as received condition. (Online version in color.)

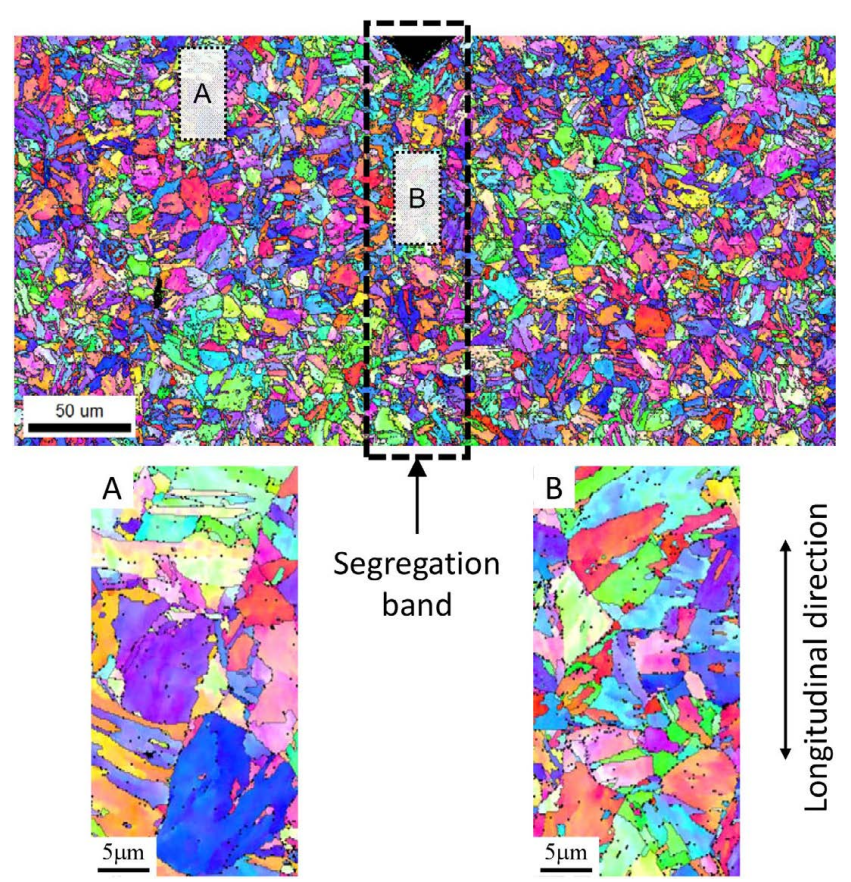

Fig. 5. IPF map of MGA heat of Grade T 91 steel in the as received condition. (Online version in color.)

direction for the as-received samples of six heats is shown in Fig. 6. The distribution of hardness was constant for MGA, MGB and MGC. On the other hand, for MGD and MGG, the hardness was slightly higher at the outer surface than at the inner surface of the tube. In the case of MGF, the hardness was lower at the outer surface than at the inner surface. Therefore, the distribution of the microstructure along the thickness direction is homogeneous for MGA, MGB and MGC, as compared with the other heats.

\subsection{Segregation of Alloying Elements}

In Section 3.2, it was confirmed that the segregation zone was distributed in layers along the thickness direction. The relationship between the segregation zone and the creep strength is discussed in this section based on the quantitative evaluation of the segregation zone.

Many $\mathrm{Nb}$-rich MX particles remain undissolved after normalizing at $1050^{\circ} \mathrm{C}$, although most $\mathrm{M}_{23} \mathrm{C}_{6}$ carbides are dissolved during normalizing. ${ }^{1-21)}$ As-received samples were renormalized for $10 \mathrm{~min}$ at $1050^{\circ} \mathrm{C}$. SEM image for MGG after renormalizing is shown in Fig. 7. Band-like regions that are not deeply etched compared with other areas were observed along the longitudinal direction of the tube. These 

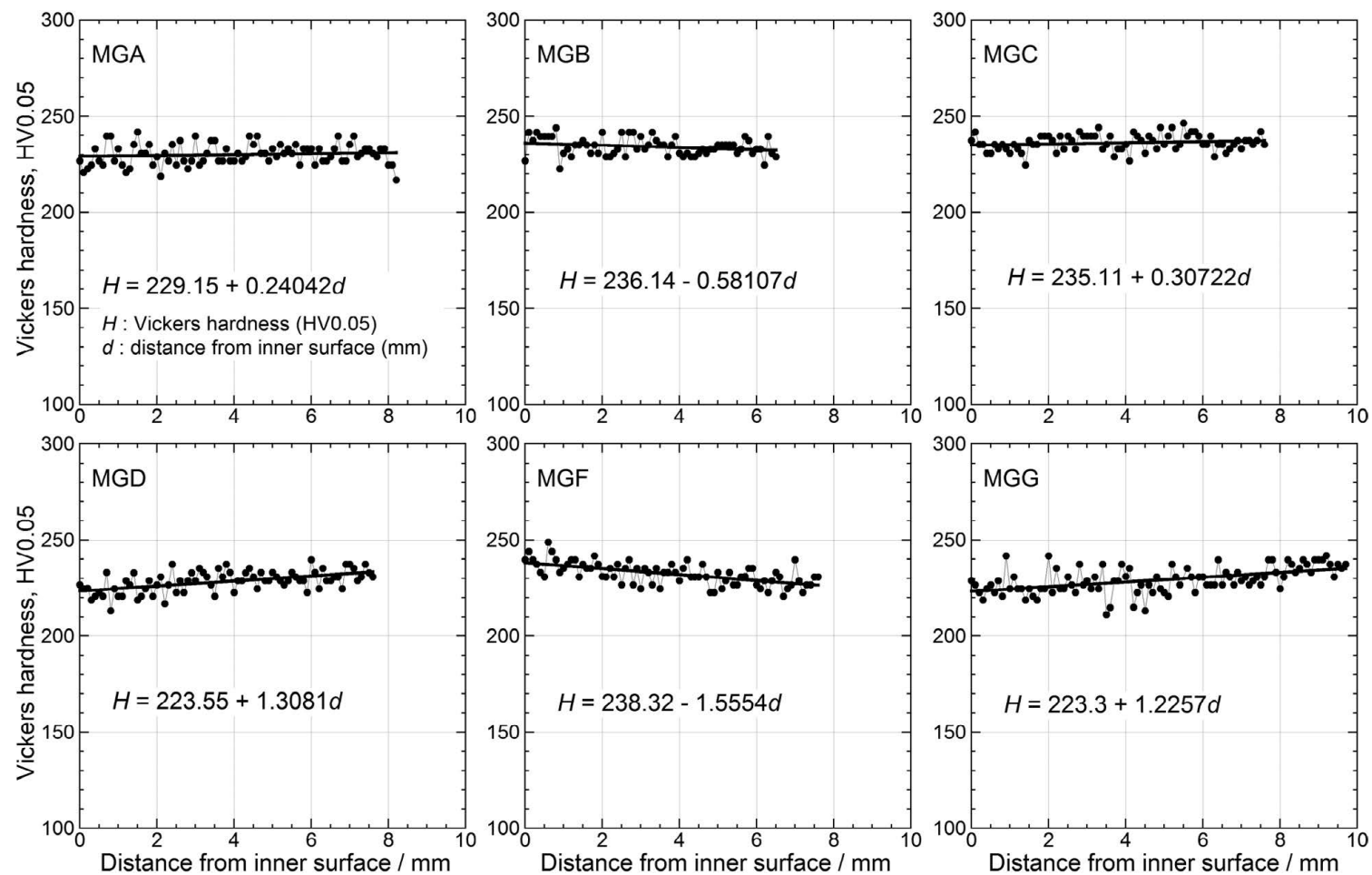

Fig. 6. Distribution of micro Vickers hardness through wall thickness of Grade T91 steels.
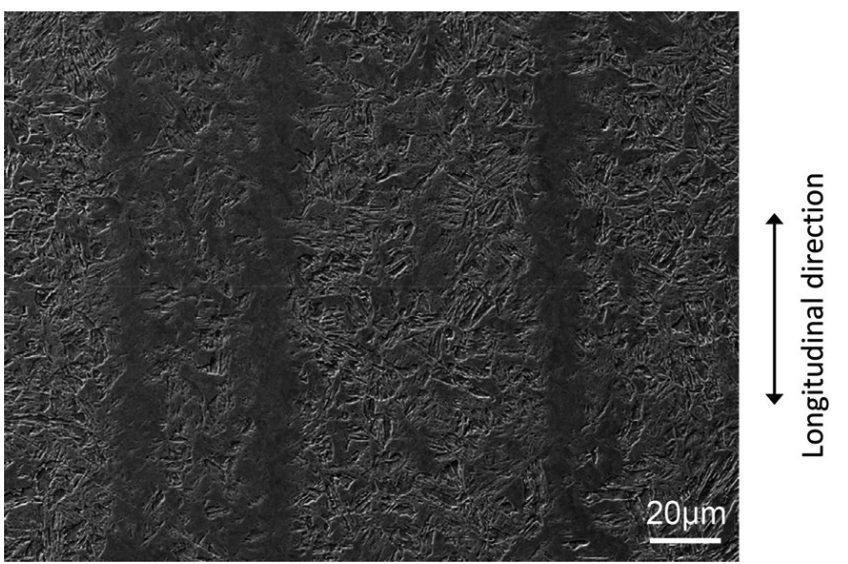

Fig. 7. Secondary electron image of MGG heat of Grade T91 steel after renormalized for $10 \mathrm{~min}$. at $1050^{\circ} \mathrm{C}$.

band-like regions may have high corrosion resistance since the $\mathrm{Cr}$ concentration is high due to the dissolution of a large number of $\mathrm{M}_{23} \mathrm{C}_{6}$ carbides.

Cr maps for MGA, MGB and MGG after renormalizing for $10 \mathrm{~min}$ at $1050^{\circ} \mathrm{C}$ were obtained from SEM-EDS, as shown in Fig. 8. The mapping location was around the center of the wall thickness. Many band-like regions with high $\mathrm{Cr}$ content were observed in MGG. The same tendency was confirmed in MGA. However, the change in contrast corresponding to the $\mathrm{Cr}$ content distribution was small in MGB. The $\mathrm{Cr}$ content changes along the wall thickness direction although the change along the longitudinal direction of the tube is small. The elemental map in Fig. 8 consists of 200 (longitudinal direction) $\times 256$ (wall thickness direction) pixels. The average $\mathrm{Cr}$ content for 200 pixels along the longitudinal direction of the tube is plotted against the distance in the wall thickness direction for MGA, MGB and MGG, as shown in Fig. 9. The fluctuation width of
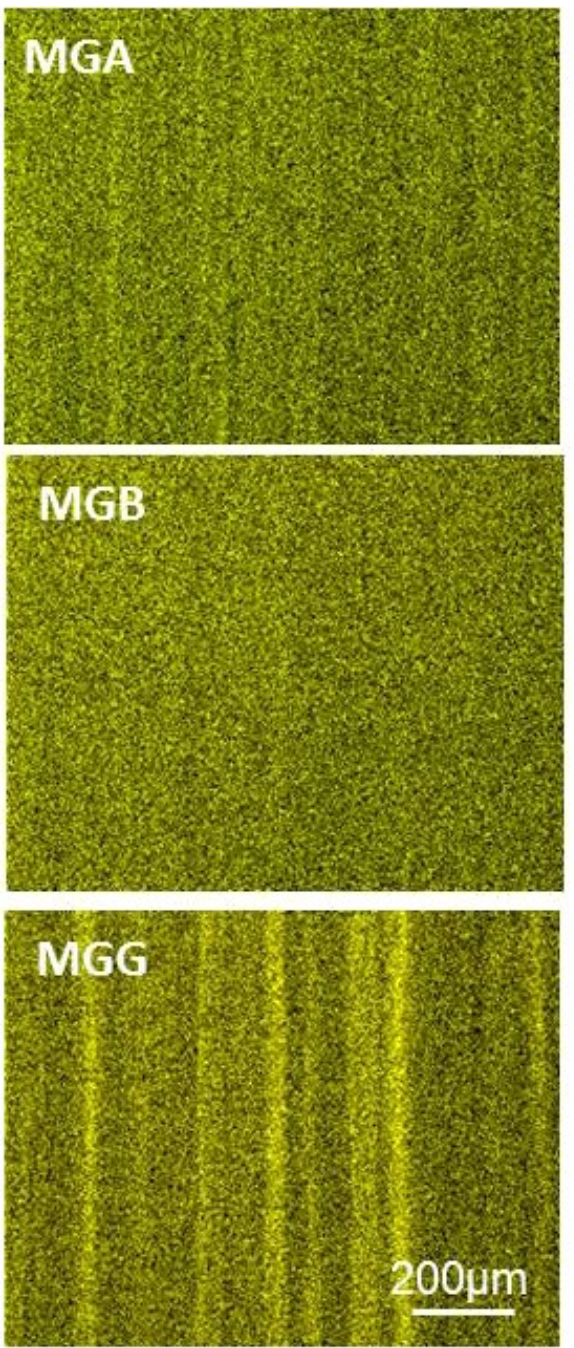

Fig. 8. Chromium mapping of MGA, MGB and MGG heats of Grade T91 steel renormalized for $10 \mathrm{~min}$. at $1050^{\circ} \mathrm{C}$. (Online version in color.) 


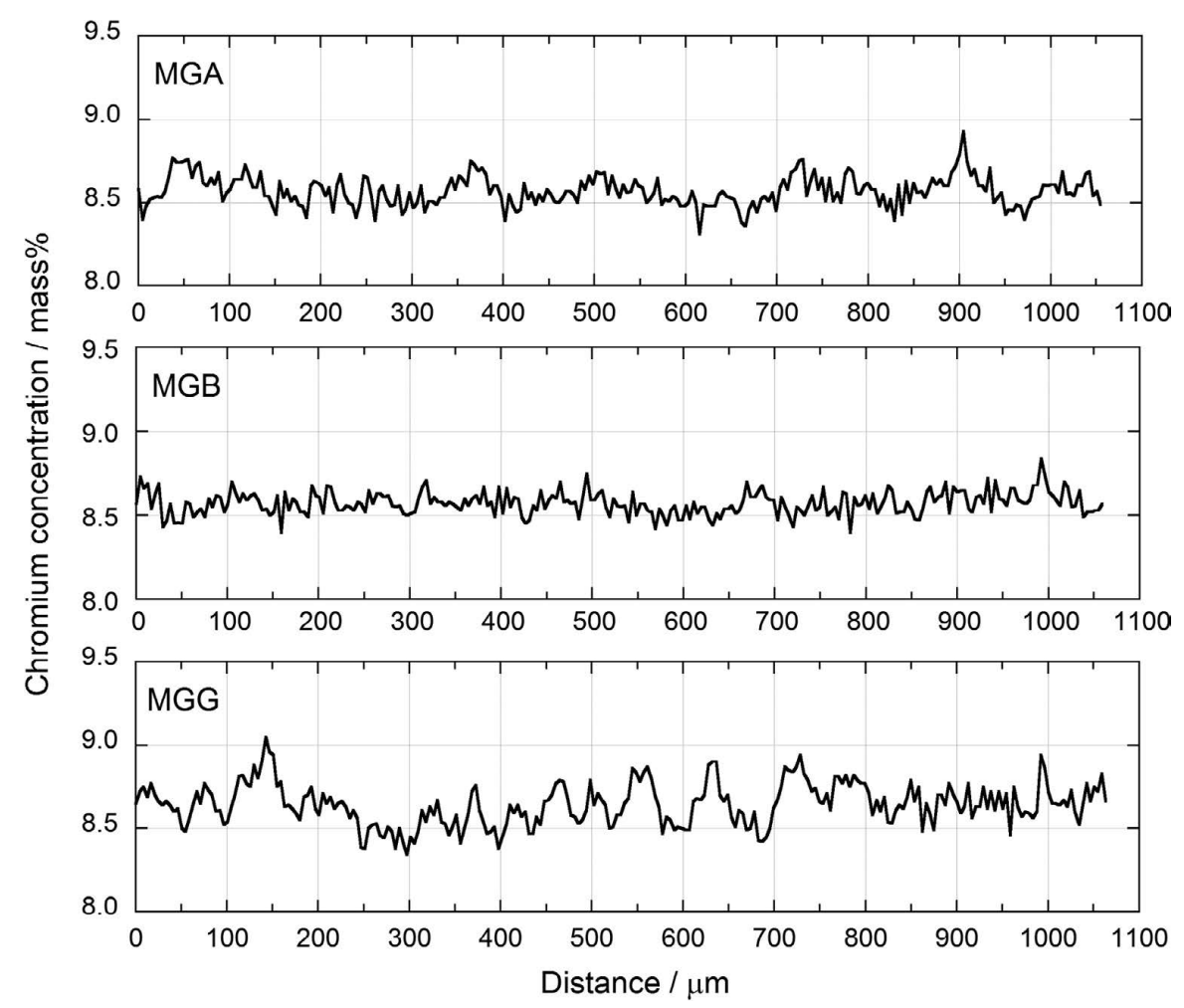

Fig. 9. Distribution of average chromium concentration along wall thickness of MGA, MGB and MGG heats of Grade T91 steel.

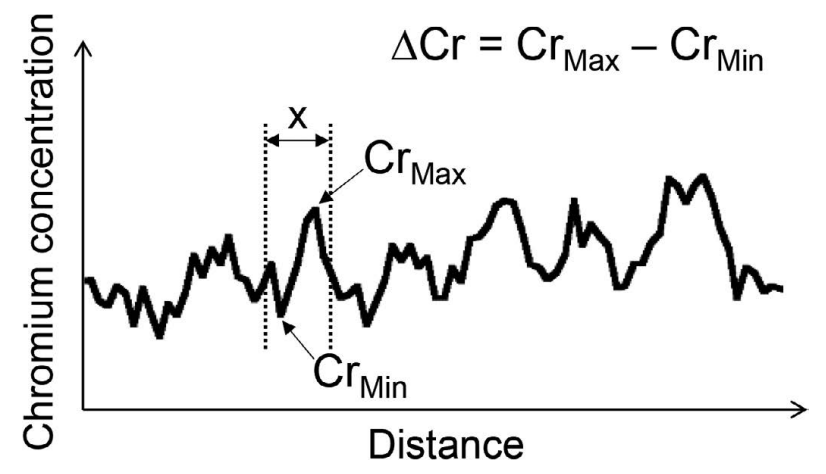

Fig. 10. Schematic illustration on the definition of $\Delta \mathrm{Cr}$.

the average $\mathrm{Cr}$ content for MGG was largest among the steels; for example, it was three times larger in MGG than in MGB. The fluctuation width of MGA was between those of MGB and MGG. The standard deviation of the average $\mathrm{Cr}$ content in the range of $1 \mathrm{~mm}$ along the wall thickness direction was estimated for all six heats. No correlation was observed between the standard deviation and the creep strength. Fick's first law of diffusion is expressed as

$$
J=-D(d C / d x)
$$

where $J$ is the flux, $D$ is the diffusion coefficient, $C$ is the concentration and $x$ is the distance. $d C / d x$ corresponds to the concentration gradient. The diffusion is promoted in proportion to the increase in concentration gradient. Therefore, a measure for quantitatively expressing the concentration gradient was proposed using the distribution of the average Cr content shown in Fig. 9.

Figure 10 shows a schematic drawing of the proposed measure. The difference between the maximum and minimum $\mathrm{Cr}$ content, $\Delta \mathrm{Cr}$, at a constant distance $(x)$ was
Table 2. Standard deviation of $\Delta \mathrm{Cr}$ along wall thickness.

\begin{tabular}{ccccccc}
\hline Heat & MGA & MGB & MGC & MGD & MGF & MGG \\
\hline SD & 0.060 & 0.047 & 0.063 & 0.068 & 0.068 & 0.079 \\
\hline
\end{tabular}

estimated in the range of $1 \mathrm{~mm}$ along the wall thickness direction. The standard deviation of $\Delta \mathrm{Cr}$ along the wall thickness direction is defined as the measure for expressing the concentration gradient of $\mathrm{Cr}$. The width and number of segregation zone changes along the wall thickness direction and depends on the heat, as shown in Fig. 8. It was assumed that the standard deviation of $\Delta \mathrm{Cr}$ along the wall thickness direction was regarded as the measure for expressing the difference in the width and number of segregation zones among the steels. The standard deviation of $\Delta \mathrm{Cr}$ was estimated when the value of $x$ was changed from 8 to $100 \mu \mathrm{m}$. A strong relationship between the standard deviation and creep strength was confirmed when the value of $x$ was about $40 \mu \mathrm{m}$. The standard deviation of $\Delta \mathrm{Cr}$ estimated when the $x$ value is $40 \mu \mathrm{m}$ is listed for each of the six heat samples in Table 2. The value of $\Delta \mathrm{Cr}$ in the range of $40 \mu \mathrm{m}$ successfully corresponds to the concentration gradients because the width of the segregation zone is about $10-20 \mu \mathrm{m}$ for the steels studied.

Figure 11 shows the relationship between the standard deviation of $\Delta \mathrm{Cr}$ and the time to rupture at $650^{\circ} \mathrm{C}$ under $50,60,70$ and $80 \mathrm{MPa}$ for the six heat samples. The time to rupture decreased with increasing the standard deviation under all the stress conditions. The correlation between the standard deviation and time to rupture becomes strong under low-stress conditions in the long term. Consequently, the creep rupture strength tends to decrease when the distribution of $\mathrm{Cr}$ concentration is drastic due to the solidifying 
segregation.

It is predicted that other alloying elements besides $\mathrm{Cr}$ are also segregated. The contents of the other alloying elements are less than 1 mass\% although the $\mathrm{Cr}$ content of the steels studied is more than 8 mass $\%$. Therefore, we focused on the $\mathrm{Cr}$ content with a large content fluctuation.

\subsection{Effect of Reduction of Segregation on Creep Strength}

In Section 3.3, the correlation between the standard deviation of $\Delta \mathrm{Cr}$ in the width range of $40 \mu \mathrm{m}$ and the time to rupture was confirmed. The time to rupture decreased when the Cr segregation was strong, as shown in Fig. 11. We tried to reduce the segregation by heat treatment and investigated the effect of the reduction on the creep strength.

The Cr maps obtained by SEM-EDS for MGG renormalized for $10 \mathrm{~min}$ at $1050^{\circ} \mathrm{C}, 10 \mathrm{~min}$ at $1200^{\circ} \mathrm{C}$ and $20 \mathrm{~h}$ at $1200^{\circ} \mathrm{C}$ are shown in Fig. 12. The $\mathrm{Cr}$ distribution after renormalization at $1200^{\circ} \mathrm{C}$ was homogeneous although a large number of $\mathrm{Cr}$ segregation zones were observed after renormalization at $1050^{\circ} \mathrm{C}$. Homogeneous $\mathrm{Cr}$ distribution may be achieved since atomic diffusion can be promoted at $1200^{\circ} \mathrm{C}$ as compared with $1050^{\circ} \mathrm{C}$. Furthermore, the

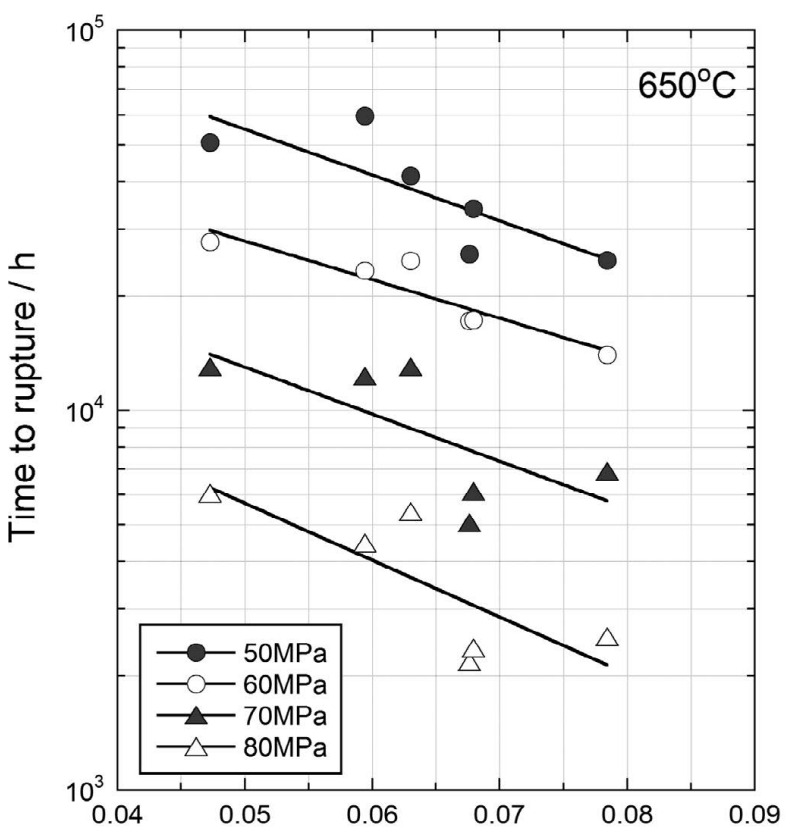

Standard deviation of $\Delta \mathrm{Cr}$ along wall thickness

Fig. 11. Relation between time to rupture at $650^{\circ} \mathrm{C}$ with standard deviation of $\Delta \mathrm{Cr}$ along wall thickness. drastic decrease in number of coarse MX particles due to the dissolution of Nb-rich MX particles can contribute to homogeneous $\mathrm{Cr}$ distribution at $1200^{\circ} \mathrm{C} .^{16,17,19)}$

Heat treatment was performed to reduce the segregation in MGG and MGB, as listed in Table 3. The MGG was renormalized for $60 \mathrm{~min}$ at $1200^{\circ} \mathrm{C}$ (No. 1) and $1250^{\circ} \mathrm{C}$ (No. 2). Renormalization for $60 \mathrm{~min}$ at $1200^{\circ} \mathrm{C}$ was performed for MGB (No. 4). Prior austenite grains were extremely coarse after renormalizing at $1200^{\circ} \mathrm{C}^{19)}$ although heat treatment at $1200^{\circ} \mathrm{C}$ can reduce the segregation. There-
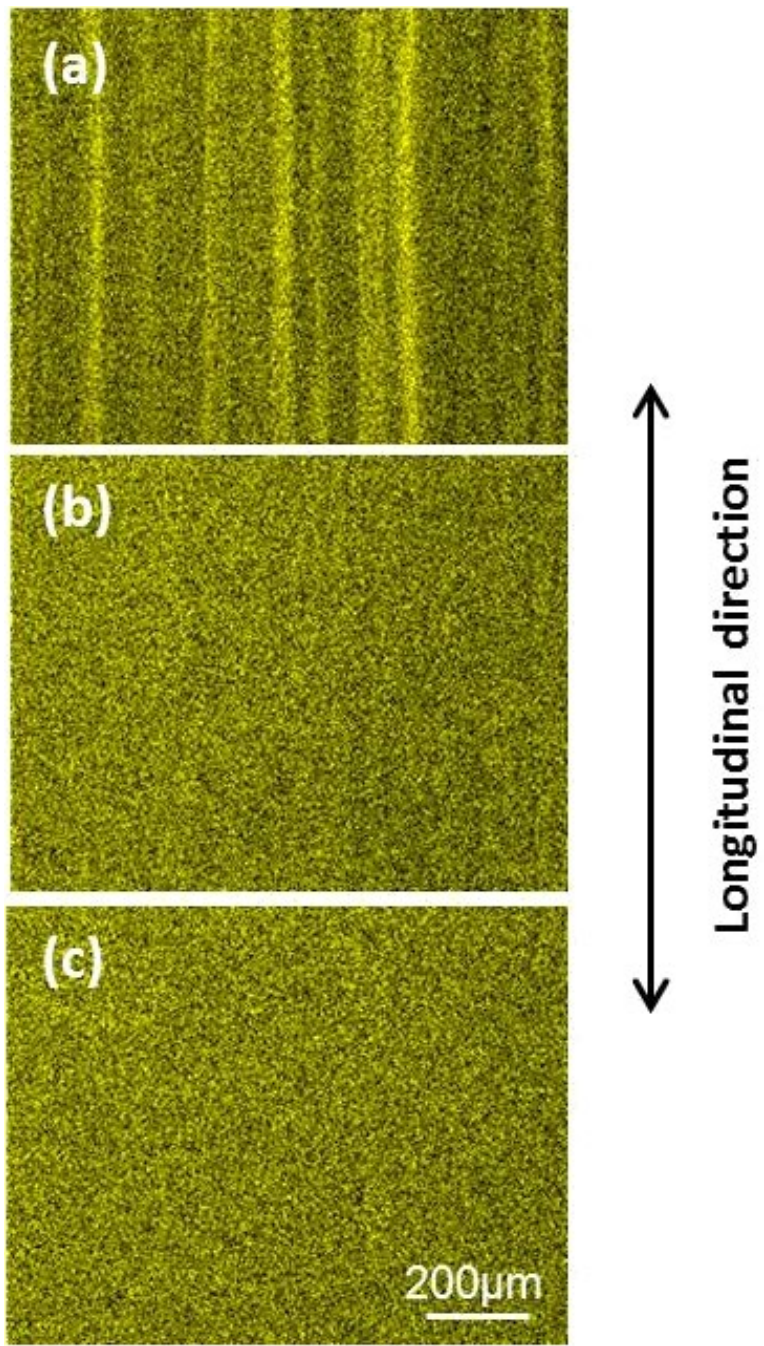

Fig. 12. Chromium mapping of MGG heat of Grade T91 steel after renormalized for (a) $10 \mathrm{~min}$. at $1050^{\circ} \mathrm{C}$ and (b) 10 min. at $1200^{\circ} \mathrm{C}$, and (c) $20 \mathrm{~h}$ at $1200^{\circ} \mathrm{C}$. (Online version in color.)

Table 3. Heat treatment condition, grain size number and hardness in the as received condition and after heat treatment.

\begin{tabular}{|c|c|c|c|c|c|c|c|c|c|}
\hline \multirow{2}{*}{ No. } & \multirow{2}{*}{ Heat } & \multicolumn{4}{|c|}{ Heat treatment condition } & \multicolumn{2}{|c|}{ As received } & \multicolumn{2}{|c|}{$\begin{array}{l}\text { After heat } \\
\text { treatment }\end{array}$} \\
\hline & & Normalizing & Tempering & Normalizing & Tempering & $\begin{array}{l}\text { G.S. } \\
\text { No. }\end{array}$ & $\begin{array}{c}\text { Hardness } \\
\text { HV }\end{array}$ & $\begin{array}{l}\text { G.S. } \\
\text { No. }\end{array}$ & $\begin{array}{c}\text { Hardness } \\
\text { HV }\end{array}$ \\
\hline 1 & \multirow{3}{*}{ MGG } & $1200^{\circ} \mathrm{C} / 60 \mathrm{~min} ., \mathrm{AC}$ & & \multirow{4}{*}{$1050^{\circ} \mathrm{C} / 30 \mathrm{~min} ., \mathrm{AC}$} & \multirow{4}{*}{$780^{\circ} \mathrm{C} / 60 \mathrm{~min} ., \mathrm{AC}$} & \multirow{3}{*}{10.7} & \multirow{3}{*}{223} & 9.4 & 231 \\
\hline 2 & & $1250^{\circ} \mathrm{C} / 60 \mathrm{~min} ., \mathrm{AC}$ & & & & & & 9.0 & 223 \\
\hline 3 & & - & - & & & & & 10.6 & 224 \\
\hline 4 & MGB & $1200^{\circ} \mathrm{C} / 60 \mathrm{~min} ., \mathrm{AC}$ & $760^{\circ} \mathrm{C} / 60 \mathrm{~min} ., \mathrm{AC}$ & & & 9.3 & 231 & 9.0 & 216 \\
\hline
\end{tabular}


fore, tempering for $60 \mathrm{~min}$ at $760^{\circ} \mathrm{C}$ was performed after renormalizing at $1200^{\circ} \mathrm{C}$ and $1250^{\circ} \mathrm{C}$, followed by normal normalizing for $30 \mathrm{~min}$ at $1050^{\circ} \mathrm{C}$ and tempering for $60 \mathrm{~min}$ at $780^{\circ} \mathrm{C}$. Heat treatment No. 3 can clarify the effect of normal normalizing and tempering on the creep strength. The prior austenite grain size is smaller in MGG than in MGB in the as-received condition. No change in prior austenite grain size was observed after the normal normalizing and tempering for MGG. On the other hand, the prior austenite grain size of MGG was coarse and almost equal to that of MGB after heat treatment to reduce the segregation. Undissolved MX carbonitrides in the segregation zone retarded the grain growth at $1050^{\circ} \mathrm{C}$. Most of these undissolved MX carbonitrides may have disappeared due to the dissolution of $\mathrm{Nb}$-rich $\mathrm{MX}$ at a temperature higher than $1200^{\circ} \mathrm{C}$, leading to drastic grain growth at $1200^{\circ} \mathrm{C}$. No drastic change in hardness was observed between before and after heat treatment.

In Fig. 13, the average $\mathrm{Cr}$ content evaluated in the same way as shown in Fig. 9 is plotted against the distance in the wall thickness direction after the heat treatment listed in Table 3. The standard deviation of $\Delta \mathrm{Cr}$ after heat treatment is estimated from Fig. 13 and listed in Table 4. The results of Fig. 13 were obtained from the center of the wall thickness. The fluctuation in $\mathrm{Cr}$ content was small for MGG (No. 1) and MGB (No. 4) after renormalizing at $1200^{\circ} \mathrm{C}$, which means that the segregation observed in $\mathrm{MGG}$ in the as-received condition was reduced. On the other hand, the effect of heat treatment at $1250^{\circ} \mathrm{C}(\mathrm{No} .2)$ on segregation is small because the fluctuation in $\mathrm{Cr}$ content is still large. This indicates that $1250^{\circ} \mathrm{C}$ is very close to the temperature of the two-phase region of austenite and ferrite. No drastic effect of heat treatment at $1050^{\circ} \mathrm{C}$ on segregation was observed.

Figure 14 shows the stress versus time-to-rupture curve

Table 4. Standard deviation of $\Delta \mathrm{Cr}$ along wall thickness.

\begin{tabular}{ccccccc}
\hline Heat & MGG & No. 1 & No. 2 & No. 3 & MGB & No. 4 \\
\hline SD & 0.079 & 0.04 & 0.058 & 0.059 & 0.047 & 0.044 \\
\hline
\end{tabular}

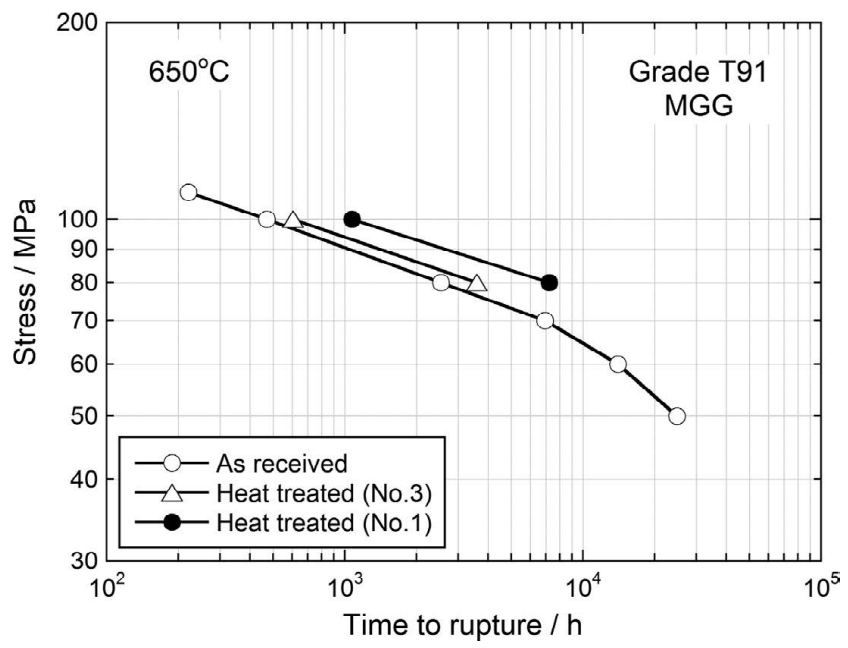

Fig. 14. Stress vs. time to rupture curves of MGG heat of Grade T91 steel in the as received condition and after heat treatment.

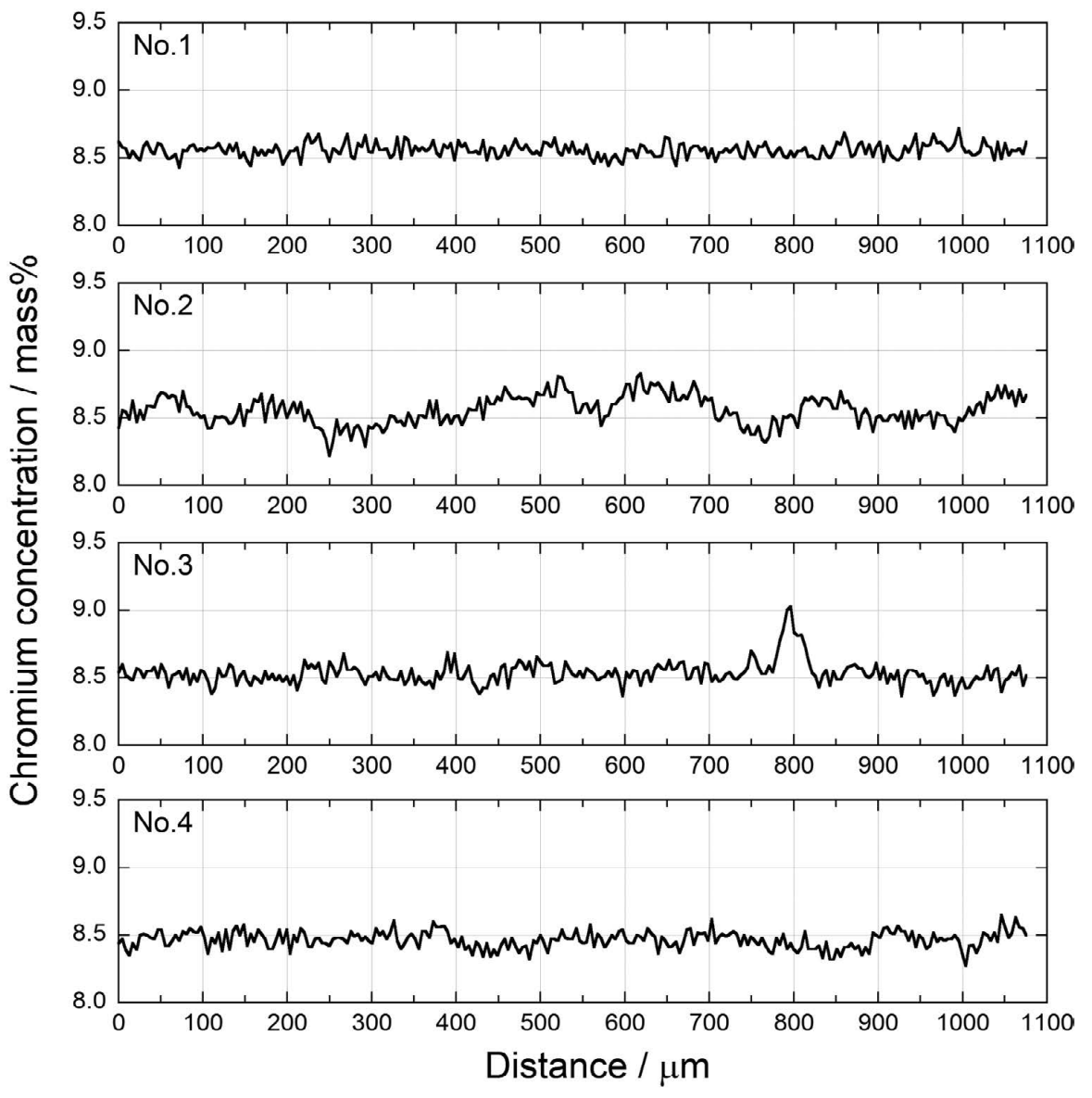

Fig. 13. Distribution of average chromium concentration along wall thickness of heat treated steels. 
at $650^{\circ} \mathrm{C}$ for MGG renormalized at $1200^{\circ} \mathrm{C}$ (No. 1) and $1050^{\circ} \mathrm{C}$ (No. 3), and the as-received MGG sample. The time to rupture of the heat-treated (No. 3) sample was 1.3-1.4 times longer than that of the as-received sample. The time to rupture of the heat-treated (No. 1) samples were 2.3 and 2.8 times longer than that of the as-received sample under 100 and $80 \mathrm{MPa}$, respectively.

Creep rate versus time curves for the heat-treated (No. 1) and as-received samples are shown in Fig. 15. Creep tests were performed at $600^{\circ} \mathrm{C}$ under $120 \mathrm{MPa}$ and at $650^{\circ} \mathrm{C}$ under $70 \mathrm{MPa}$. The creep rate was smaller in the heat-treated (No. 1) sample than in the as-received sample under both creep test conditions. The creep strength was apparently improved by the reduction of segregation because the heattreated sample was at the beginning of tertiary creep even after the as-received sample ruptured. Creep tests under low-stress conditions are ongoing. The improvements of creep strength by reduced segregation for more than 10000 $\mathrm{h}$ at $600^{\circ} \mathrm{C}$ and $650^{\circ} \mathrm{C}$ will be investigated in future.

\subsection{Effect of Segregation on Creep Strength}

The presence of coarse prior austenite grains after heat treatment for the reduction of segregation can affect the creep strength. It was reported that in modified $9 \mathrm{Cr}-1 \mathrm{Mo}$ steel, no effect of grain size on creep strength was observed for about $10000 \mathrm{~h}$ although long-term creep strength for about $100000 \mathrm{~h}$ depends on the grain size. ${ }^{22)}$ Therefore, the
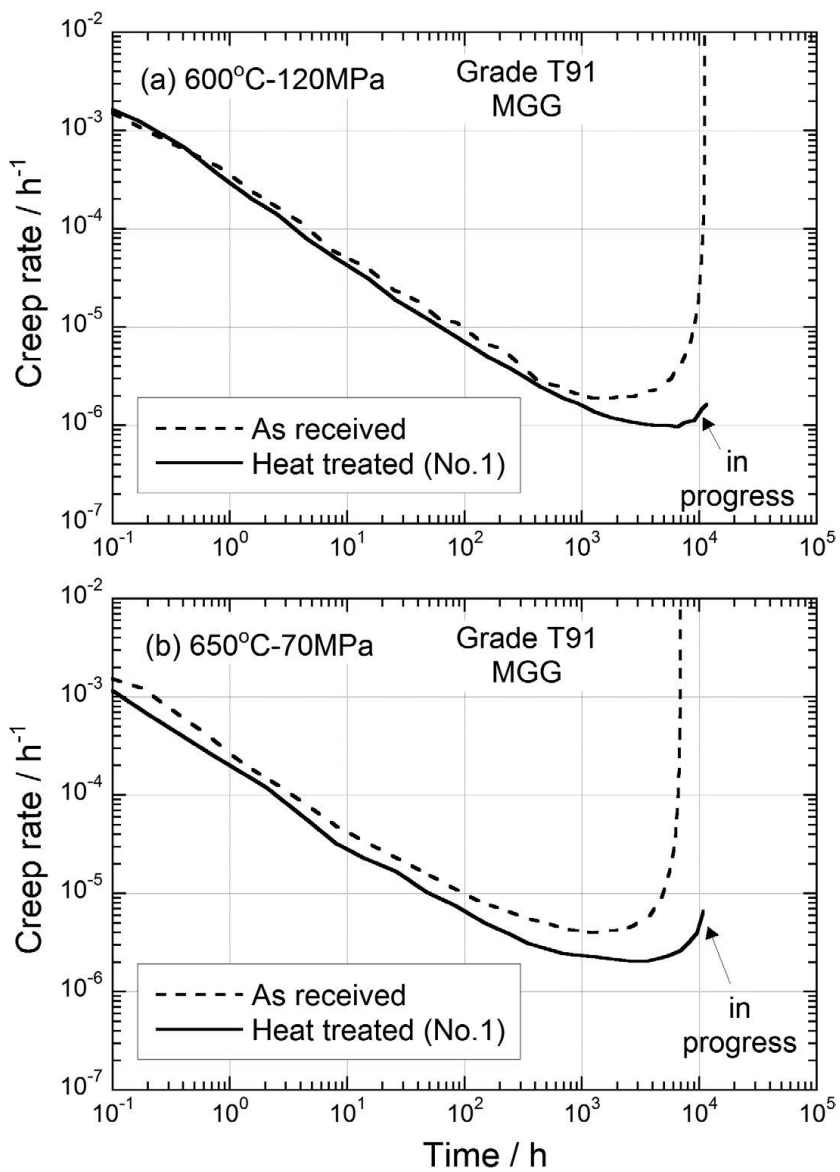

Fig. 15. Creep rate vs. time curves at (a) $600^{\circ} \mathrm{C}-120 \mathrm{MPa}$ and (b) $650^{\circ} \mathrm{C}-70 \mathrm{MPa}$ of MGG heat of Grade T91 steel in the as received condition and after normalizing heat treatment at $1200^{\circ} \mathrm{C}$. coarse grains cannot explain the creep strength improvement of about $10000 \mathrm{~h}$ by the heat treatment for the reduction of segregation shown in Fig. 15.

The number densities of $\mathrm{M}_{23} \mathrm{C}_{6}$ carbide, V-rich $\mathrm{MX}$ and $\mathrm{Nb}$-rich MX were measured in the segregation zone and other areas. The correlation between the number density of $\mathrm{M}_{23} \mathrm{C}_{6}$ carbide and the creep strength was confirmed, while no correlation between that of MX and strength was observed. Figure 16 shows the relationship between the number density of $\mathrm{M}_{23} \mathrm{C}_{6}$ carbide in the segregation zone and other areas and the time to rupture at $600^{\circ} \mathrm{C}$ and $650^{\circ} \mathrm{C}$ for MGB and MGG. At the segregation zone, there was no difference in the number density before creep. After creep rupture, however, the number density was drastically lower in MGG than MGB. At the outside of the segregation zone, the number densities of both the as-received and creep ruptured samples were smaller in MGG than MGB. It is concluded that the number density of $\mathrm{M}_{23} \mathrm{C}_{6}$ carbide became smaller due to the low content of alloying elements at the outside of the segregation zone compared to the inside of the segregation zone. This indicates that precipitation strengthening outside the segregation zone is smaller than that inside the segregation zone.

Figure 17 shows the relationship between the length of high-angle boundaries and the time to rupture at $600^{\circ} \mathrm{C}$ under $80 \mathrm{MPa}$ and at $650^{\circ} \mathrm{C}$ under $60 \mathrm{MPa}$. The length of
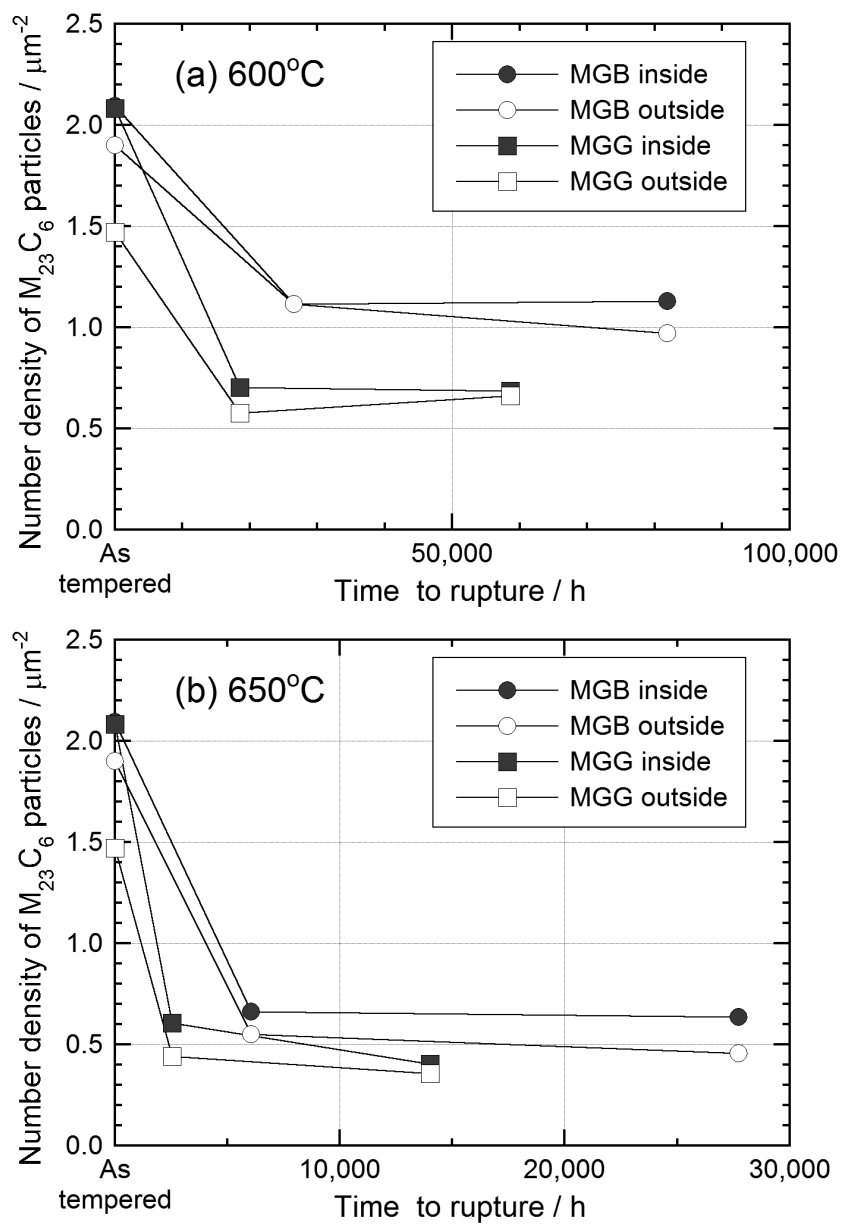

Fig. 16. Changes in number density of $\mathrm{M}_{23} \mathrm{C}_{6}$ carbide particles inside and outside of segregation band of MGB and MGG heats of Grade T91 steel during creep exposure at (a) $600^{\circ} \mathrm{C}$ and (b) $650^{\circ} \mathrm{C}$. 

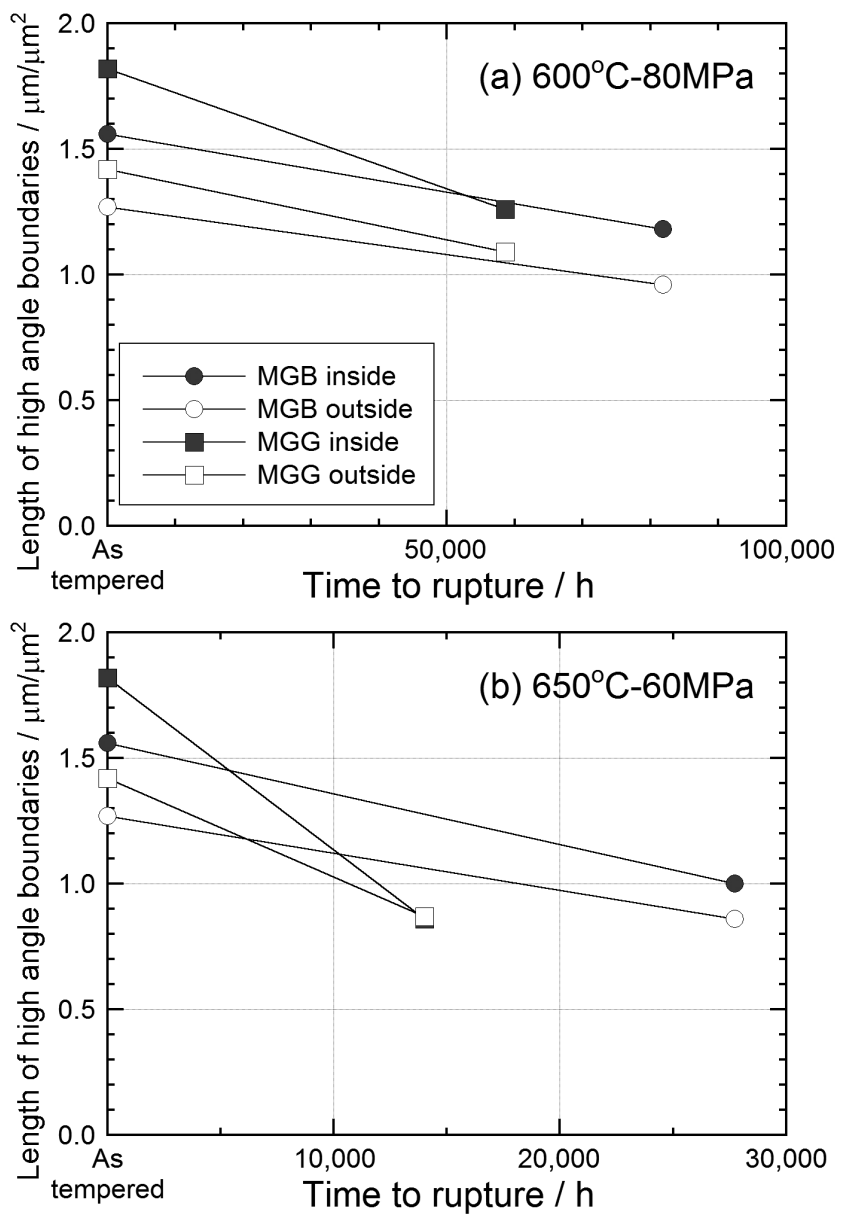

Fig. 17. Changes in length of high angle boundaries for inside and outside of segregation band of MGB and MGG heats of Grade T91 steel during creep exposure at $600^{\circ} \mathrm{C}-80 \mathrm{MPa}$ and $650^{\circ} \mathrm{C}-60 \mathrm{MPa}$.

the high-angle boundaries was measured in the segregation zone and other areas. In this case, a high-angle boundary means a boundary with a misorientation angle of $5^{\circ}$ to $180^{\circ}$. The length of high-angle boundaries before creep was larger in MGG than in MGB for the segregation zone and other areas. This corresponds to the fine grains of MGG as compared with MGB. However, the length of the highangle boundary of MGG significantly decreased after creep exposure as compared with MGB. This decrease was larger at $650^{\circ} \mathrm{C}$ than at $600^{\circ} \mathrm{C}$.

The relationship between the kernel average misorientation (KAM) and the time to rupture is shown at $600^{\circ} \mathrm{C}$ under $80 \mathrm{MPa}$ and at $650^{\circ} \mathrm{C}$ under $60 \mathrm{MPa}$ in Fig. 18. The KAM was measured in the segregation zone and other areas. The KAM value is the average of the entire measurement area. The KAM decreased after creep rupture in MGB and MGG. The KAM of MGG significantly decreased at $650^{\circ} \mathrm{C}$ as compared with MGB although the decrease in MGB was almost the same as that in $\mathrm{MGG}$ at $600^{\circ} \mathrm{C}$. The decrease in dislocation density after creep may be faster in MGG than in MGB because the correlation between the KAM and dislocation density has been confirmed. ${ }^{23)}$

Consequently, the decrease in number density of $\mathrm{M}_{23} \mathrm{C}_{6}$, length of high-angle boundary and dislocation density was significant in both the segregation and non-segregation zones of MGG with strong segregation, leading to the
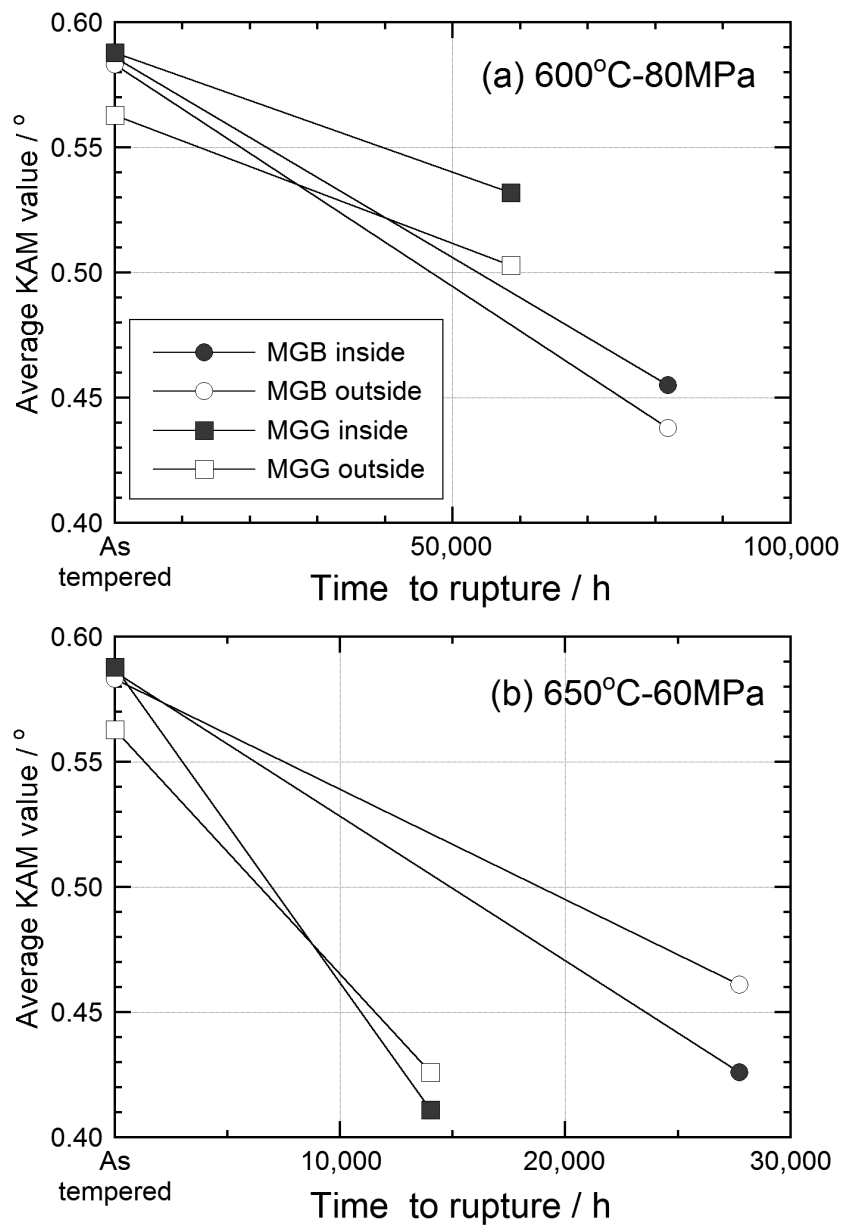

Fig. 18. Changes in average KAM value for inside and outside of segregation band of MGB and MGG heats of Grade T91 steel during creep exposure at $600^{\circ} \mathrm{C}-80 \mathrm{MPa}$ and $650^{\circ} \mathrm{C}-60 \mathrm{MPa}$.

acceleration of the recovery of martensite. In strongly segregated steel, prior austenite grains are very fine due to the pinning effect of undissolved precipitates. Furthermore, the concentration gradient of alloying elements can promote microstructural changes due to diffusion in the segregated steel. The concentration gradient of Fe was also confirmed in the same way as $\mathrm{Cr}$ shown in Fig. 9. The concentration gradient of Fe can promote the recovery of martensite due to the diffusion of $\mathrm{Fe}$. The concentration gradient of $\mathrm{Cr}$ can accelerate the coarsening of $\mathrm{M}_{23} \mathrm{C}_{6}$ due to $\mathrm{Cr}$ diffusion, indicating that the decrease in the number density of $\mathrm{M}_{23} \mathrm{C}_{6}$ pinned to a high-angle boundary can be promoted. Creep strength degradation in segregated steel can mainly be attributed to microstructural changes by diffusion because the heat-to-heat variation in creep strength is significant at higher temperatures. To obtain good creep properties, it is necessary to reduce the segregation since microstructural changes due to diffusion are promoted by the concentration gradient of the alloying elements.

\section{Conclusions}

To clarify the reason for the heat-to-heat variation in the creep strength of ASME SA-213/SA-213M Grade T91 steels, the effect of the initial microstructure on the creep strength was investigated. The results are summarized as 
follows.

(1) Heat-to-heat variation in creep strength was observed in the six steels examined. The variation increased with increasing testing temperature. No correlation was found between the creep strength and $\mathrm{Ni}$ and $\mathrm{Al}$ contents at $650^{\circ} \mathrm{C}$ showing apparent heat-to-heat variation in creep strength.

(2) A large number of layered contrasts were observed parallel to the longitudinal direction of the boiler tube. Many precipitates and inclusions were observed in the layered contrasts region. It was predicted that the areas where alloying elements concentrated due to solidifying segregation were thinly rolled by hot extrusion, causing the formation of a layered microstructure with a different concentration of alloying elements.

(3) The difference between the maximum and minimum $\mathrm{Cr}$ content, $\Delta \mathrm{Cr}$, at a constant distance $(x)$ was defined based on the $\mathrm{Cr}$ content distribution along the wall thickness direction. A good correlation was found between the standard deviation of $\Delta \mathrm{Cr}$ and the time to rupture when the $x$ value was about $40 \mu \mathrm{m}$.

(4) The segregation was reduced after renormalizing at $1200^{\circ} \mathrm{C}$. No clear reduction of segregation was observed after renormalizing at $1250^{\circ} \mathrm{C}$. This can be attributed to the fact that $1250^{\circ} \mathrm{C}$ is very close to the temperature of the two-phase region of austenite and ferrite.

(5) Renormalizing at $1200^{\circ} \mathrm{C}$ and tempering at $760^{\circ} \mathrm{C}$ followed by normal heat treatment of normalizing for $30 \mathrm{~min}$ at $1050^{\circ} \mathrm{C}$ and tempering for $60 \mathrm{~min}$ at $780^{\circ} \mathrm{C}$ extended the creep rupture life by a factor of about 2.3-2.8 at $650^{\circ} \mathrm{C}$ under 80 and $100 \mathrm{MPa}$. The improvement in creep strength by the reduction of segregation was also confirmed under long-term conditions such as $650^{\circ} \mathrm{C} / 6920 \mathrm{~h}$ and $600^{\circ} \mathrm{C} / 11122 \mathrm{~h}$.

(6) The decrease in number density of $\mathrm{M}_{23} \mathrm{C}_{6}$, length of high-angle boundaries and dislocation density was significant in both the segregation and non-segregation zones for strongly segregated steel. This indicates that the recovery of martensite was promoted by the large concentration gradient of alloying elements in strongly segregated steel.

(7) Consequently, the presence of segregation decreases the creep strength since microstructural changes controlled by diffusion are promoted due to the segregation. It is necessary to reduce the segregation and obtain a homogeneous distribution of alloying elements to improve the creep strength.

\section{Acknowledgement}

This work is the result of joint research among Hitachi Metals Ltd., IHI Corporation, Mitsubishi Heavy Industries, Ltd. and the National Institute for Materials Science for 2015FY, and Electric Power Development Co., Ltd.,
Mitsubishi Heavy Industries, Ltd. and the National Institute for Materials Science for 2016FY. The authors thank Dr. Toru Hara (NIMS), Ms. Yuka Hara (NIMS) and Ms. Akiko Nakamura (NIMS) for their support with the microstructural observation and Mr. Kazuhiko Iida (NIMS) for his support with the heat treatment.

\section{REFERENCES}

1) F. Masuyama: ISIJ Int., 41 (2001), 612.

2) V. Foldyna, Z. Kuboň, A. Jakobová and V. Vodárek: Microstructural Development and Stability in High Chromium Ferritic Power Plant Steels, The Institute of Materials, London, (1997), 73.

3) A. Strang and V. Vodarek: Microstructural Stability of Creep Resistant Alloys for High Temperature Plant Applications, The Institute of Materials, London, (1998), 117.

4) H. Kushima, K. Kimura and F. Abe: Tetsu-to-Hagané, 85 (1999), 841 (in Japanese).

5) S. J. Brett, D. L. Oates and C. Johnston: Proc. Creep \& Fracture in High Temperature Components - Design \& Life Assessment Issues, DEStech Publications, Inc., Lancaster, (2005), 563.

6) ASME BPV Code Case 2864: 2016, 9Cr-1Mo-V Material Section I.

7) Thermal and Nuclear Power Engineering Society: The Material Specification in the Technical Regulation of Equipment for Thermal Power Plant, TENPES, Tokyo, (2007), 153 (in Japanese).

8) Thermal and Nuclear Power Engineering Society: The Material Specification in the Technical Regulation of Equipment for Thermal Power Plant, TENPES, Tokyo, (2014), 147 (in Japanese).

9) M. Tabuchi and Y. Takahashi: Proc. ASME 2006 Pressure Vessels and Piping/ICPVT-11 Conf., ASME, New York, (2006), PVP2006ICPVT-11-93350.

10) M. Yaguchi, T. Matsumura and K. Hoshino: Proc. ASME 2012 Pressure Vessels and Piping Conf. (PVP2012), ASME, New York, (2012), PVP2012-78393.

11) The Life Evaluation Formula of High Chromium Steels for Thermal Power Plant, Nuclear and Industrial Safety Agency (NISA), The Ministry of Economy, Trade and Industry (METI), NISA-234c-05-9, (2005), http://www.meti.go.jp/policy/safety_security/industrial_safety/ oshirase/2005/files/171214-1.pdf, (accessed 2005-12-14) (in Japanese).

12) The Life Evaluation Formula of High Chromium Steels for Thermal Power Plant, The Ministry of Economy, Trade and Industry (METI), (2014), http://www.meti.go.jp/policy/safety_security/industrial_safety/ oshirase/2014/06/2606303-.html, (accessed 2014-5-30) (in Japanese).

13) K. Kimura and M. Yaguchi: Proc. ASME 2016 Pressure Vessels and Piping Conf. (PVP2016), ASME, New York, (2016), PVP201663355 .

14) NIMS Creep Data Sheet, No. 43A, National Institute for Materials Science (NIMS), Tsukuba, (2014).

15) ASME BPV Code, Section II-D: 2017, SA-213/SA-213M Grade T91.

16) The Material Specification in the Technical Regulation of Equipment for Thermal Power Plant, Thermal and Nuclear Power Engineering Society (TENPES), Tokyo, (2016), 160 (in Japanese).

17) K. Kimura, K. Sawada and H. Kushima: Advances in Materials Technology for Fossil Power Plants, ed. by D. Gandy et al., ASM International, Materials Park, OH, (2011), 732.

18) K. Kimura and Y. Takahashi: Proc. ASME 2012 Pressure Vessels and Piping Conf. (PVP2012), ASME, New York, (2012), PVP201278323.

19) A. Matsuzaki, Y. Saito, O. Watanabe, C. Shiga and I. Nakagawa: Tetsu-to-Hagané, 76 (1990), 1108 (in Japanese).

20) M. Yoshino, Y. Mishima, Y. Toda, H. Kushima, K. Sawada and K. Kimura: ISIJ Int., 45 (2005), 107.

21) S. Obara, T. Wakai, T. Asayama, Y. Yamada and T. Nakazawa: Tetsu-to-Hagané, 95 (2009), 417 (in Japanese).

22) K. Maruyama, J. Nakamura, N. Sekido and K. Yoshimi: Mater. Sci. Eng. A, 696 (2017), 104.

23) K. Kubushiro, Y. Sakakibara and T. Ohtani: J. Soc. Mater. Sci. Jpn., 64 (2015), 106 (in Japanese) 